\title{
Retirement Financial Behaviour: How Important Is Being Financially Literate?
}

\author{
J. C. Hauff ${ }^{1}$ (D) A. Carlander ${ }^{2} \cdot$ T. Gärling $^{2} \cdot$ G. Nicolini $^{3}$
}

Received: 28 June 2019 / Accepted: 19 December 2019 / Published online: 8 January 2020

(C) The Author(s) 2020

\begin{abstract}
Using Item Response Theory to analyse survey data from a representative sample of 551 Swedish citizens, a new 16-question measure of fact-based financial literacy is developed and validated. Uni-dimensionality of the measure is verified, and expected correlations are observed with an existing measure of fact-based financial literacy, a measure of subjective financial literacy or confidence, and age, gender, and income. A significant impact of fact-based and subjective financial literacy are found on three time-ordered stages of individuals' retirement behaviour: planning, saving, and investment management. It is concluded that policies increasing final literacy are important in different phases of the life cycle.
\end{abstract}

Keywords Financial literacy · Financial retirement behaviour · Survey data $\cdot$ Literacy measures

Electronic supplementary material The online version of this article (https://doi.org/10.1007/s10603-01909444-x) contains supplementary material, which is available to authorized users.

J. C. Hauff

Jeanette.hauff@handels.gu.se

A. Carlander

anders.carlander@gu.se

T. Gärling

tommy.garling@psy.gu.se

G. Nicolini

nclgnn00@uniroma2.it

1 School of Business, Economics and Law, University of Gothenburg, Vasagatan 1, 405

30 Gothenburg, Sweden

2 Department of Psychology, University of Gothenburg, Haraldsgatan 1, 40530 Gothenburg, Sweden

3 Tor Vergata, Via Cracovia n.50, 00133 Rome, Italy 


\section{Background}

Financial literacy potentially influences retirement financial behaviour entailing planning, saving, and investment management. In this paper, we argue that saving for retirement involves these three stages, sometimes with varying demands on the individual, and that simultaneously assessing the impact of financial literacy on each stage will provide new knowledge of individual retirement financial behaviour compared with previous research which has investigated each stage separately. In order to determine this influence, we develop a new objective fact-based measure of financial literacy to better capture the different levels of literacy that in different individuals have impacts on retirement financial behaviour.

A potential weakness in previous research linking financial behaviour to financial literacy is that, for almost two decades, studies have largely relied on a measure of financial literacy consisting of the same limited set of three or five standard survey questions (Lusardi and Mitchell 2007). A limited number of questions may, although connected to retirement saving behaviours, fail to fully explain individual variation in these behaviours. We therefore include questions tapping a wider variety of topics in developing a new measure of financial literacy, based on Item Response Theory (IRT) as previously used by Knoll and Houts (2012). In contrast to Knoll and Houts, we are able to ascertain uni-dimensionality of the fact-based knowledge construct, and we also use items with varying degree of difficulty, hence, enabling us to more reliably measure varying individual levels of financial literacy.

In contemporary market societies, financial decision-making has for a long time been of paramount importance to individuals. Despite this already heightened focus, arguably, the importance of saving decisions has grown during the last decades. One reason is the new policies increasing the responsibility imposed on individual citizens for saving to retirement (Benartzi and Thaler 2007). Worldwide today, pension systems enable and encourage active participation, and the income stream after retirement increasingly relies on private savings (Carlsson Hauff et al. 2014; Poterba et al. 2008). Hence, financial decisions with consequences for retiree income are now faced by many citizens and not only by professionals.

Empirical evidence indicates that the increasing individual responsibility for retirement savings results in that people fail to save enough (Munnell et al. 2007). Combined with an increased need for retirement income due to longer life expectancies, the resulting insufficient funds of retirement savings constitute a serious concern (McKenzie and Liersch 2011). This concern motivates the focus of the present study of lay people's ability to handle an increased financial responsibility. One potential cause of an insufficient way to deal with financial responsibility is individuals' low involvement in financial matters. Several studies have documented that low involvement leads to an incomplete information search and passivity in choice of funds in pension plans (e.g., Hauff 2006). A proactive solution to insufficient involvement is communication with a strengthened focus on positive feelings (Carlsson Hauff et al. 2014, 2016; Weber 2004).

Another cause of not taking financial responsibility that is the main focus of this paper is insufficient financial knowledge and skill. The task of rationally deciding how to accumulate and consume assets over the life cycle is regarded so arduous that people refrain from making any choice at all (Benartzi and Thaler 2007). Should individuals prove to lack sufficient financial knowledge and skill, the remedy may be either education (van Rooij et al. 2012) or measures that simplify saving for retirement, for instance nudging people to make retirement saving choices in their best interest (Thaler and Sunstein 2008). Individuals' inability to take an increased financial responsibility due to lack of knowledge and skill is targeted in studies of financial literacy that 
describe, analyse, and quantify individuals' ability to solve problems they encounter when making financial decisions. The significant role of financial literacy is documented in both financial retirement planning (van Rooij et al. 2012), wealth accumulation (Behrman et al. 2012), and attitude towards risky assets (Nicolini et al. 2017; van Rooij et al. 2011).

It may be noted that the questions about retirement saving (planning for retirement saving, saving for retirement, and constructing a retirement savings portfolio) leave aside short-term and buffer saving. In Sweden, where the present study is performed, state income pensions cover a large majority of citizens (amounting to around 40-50\% of final salary), as does workrelated pensions. System-wise, this is comparable with the situation in, e.g., the United States of America (USA) where the average level of social security lies around $\$ 1,400$ per month, hence, implying (just as in the Swedish case) a necessity to save privately on top. The questions we ask pertaining to the retirement savings portfolio as a whole make the results applicable even in contexts where state income pensions and work-related pensions amount to a smaller part of individuals' retirement provisions.

The remainder of the paper is organized as follows. In the next section, we review previous research of retirement financial behaviour with particular focus on the relationship with financial literacy. This is followed by sections reporting our empirical study of the influence of financial literacy in different stages of retirement financial behaviour.

\section{Literature Review}

\section{Retirement Financial Behaviour}

Paralleling the recent growing importance of individual choice in retirement savings (McKenzie and Liersch 2011), consumer behaviour research increasingly focuses on understanding the precautionary behaviour of retirement savings of the general public (Ooijen et al. 2015). Traditionally, the point of departure here are the economic motives for saving, such as the life cycle model where rational agents save and borrow in order to smooth consumption over the life cycle (Modigliani 1986). However, several more recent observations of actual savings behaviour are not in line with this rational model; e.g., the observed insufficient saving rates do not fit with the assumptions of the life cycle model (Schooley and Drecnik Worden 2013). The upsurge in behaviourally rooted explanations of retirement saving may hence be viewed as an attempt to address the discrepancies between individual saving as predicted from the life cycle model and actual observations.

Retirement savings behaviour relies specifically on two assumptions critical to the life cycle model. One is the assumption that individuals know how to optimize over the life cycle in the way the life cycle model implies, and the other that people are able to exert sufficient selfcontrol to do this (Benartzi and Thaler 2007). If these assumptions are not met, the negative consequences may be substantial. The second assumption about lack of self-control entails that individuals despite understanding the need for accumulating funds for use later in life fail to sufficiently decrease current consumption with severe consequences for retiree income. The first assumption that the individual actually knows how to optimize, central to the present study, is even more critical. That people lack the cognitive ability to perform the optimization task implied by the life cycle model has been known for a long time (Simon 1955). The coping strategies used by individuals to compensate for cognitive shortcomings are investigated in the plethora of studies of judgment heuristics (Katsikopoulos 2011). 
The present study measures financial literacy assuming that low levels of financial literacy contribute to why individuals are unable to perform the optimizing task but instead rely on judgment heuristics. Hence, knowledge of level of financial literacy may, as knowledge of judgment heuristics, serve as a tool for legislators in structuring pension systems (through, e.g., automatic enrollment and default design; Benartzi and Thaler 2004; Madrian and Shea 2001).

\section{Financial Literacy}

Previous research contains several definitions of financial literacy. Some focus on efficiency of actual financial decision-making (Noctor et al. 1992), others on skills in comprehending, analyzing, managing, and communicating financial matters (Vitt et al. 2000). A common notion in studies of consumer knowledge, spanning the early work of Bloom et al. (1956) to Alba and Hutchinson's (1987) seminal work, is the distinction between objective knowledge (or "knowledge of specifics") and familiarity (defined by Alba and Hutchinson 1987, as the number of product-related experiences). Another common notion is that knowledge is not a unitary construct but is partly fact-based and objective, partly subjective, implying that individuals' perceptions of their level of knowledge is distinct from (but usually related to) objective knowledge (Moorman et al. 2004). Not only objective but also subjective financial knowledge has implications for financial behaviour. An accurate perception of one's knowledge is essential for being self-confident in applying the objective knowledge, as witnessed by responsible financial management behaviour (Perry and Morris 2005) and sensible financial choices (Hauff 2006). A third dimension is familiarity, leading to quicker and more effortless evaluations (Schaefer 1997).

The three knowledge dimensions (objective, subjective, and familiarity) are common ingredients of definitions of financial literacy (Huston 2010). The objective knowledge dimension (defined by Huston 2010, p. 307, as "stock of knowledge [...] related to essential personal finance concepts and products") is emphasized, as is the application dimension (described by Huston 2010, as the ability and confidence to apply and use financial knowledge, and hence corresponding to both subjective knowledge and familiarity). The definition proposed in Huston (2010), and adhered to in the present study, accordingly includes both understanding (objective knowledge) and use (subjective knowledge and familiarity): "Financial literacy measures how well an individual can understand and use personal finance-related information" (p. 306). Note that objective and subjective knowledge are related - an expected result if objective knowledge (what an individual actually knows) influences subjective knowledge (what an individual believes that he or she knows). In a meta-analysis of studies investigating the relationship between subjective and objective knowledge, Carlson et al. (2009) found that the correlation varies. The correlation is generally strong in a product setting as well as for search-related goods. A comparison of correlations focusing solely on financial services revealed correlations varying from $r=0.2$ in a study of financial services in general (Devlin 2011) to $r=0.4$ in a study focusing on investment-related financial services (Chiou et al. 2002).

It has been argued that a combination of objective and subjective knowledge should be included in measures of financial literacy since the aim is to understand the ability to make decisions and handle personal finances (Huston 2010; Remund 2010). The bulk of studies using measures of financial literacy still focuses primarily on objective knowledge (Nicolini et al. 2013). In the following, we comply with practice and use the term "financial literacy" even though "financial knowledge" would be more accurate. Additionally, since financial services are diverse, it needs to be made explicit what kind of services are targeted. Huston 
(2010) finds in a review of 71 studies of financial literacy that questions have been posed about at least three knowledge areas, money basics (including time value of money or purchasing power), transfers of resources between time periods (borrowing or investing), and protecting resources (insurance or risk management). Previous studies vary in their inclusion of these areas. Most of them include several different topics (such as the most widely used composite measure developed by Lusardi and Mitchell 2007).

\section{Measurement of Financial Literacy}

The five questions originally used in the Health and Retirement Study in 2004 (HRS 2004) served as a starting point for the measurement of financial literacy. These questions tap knowledge of inflation, interest rates, mortgages, bond pricing, and diversification in investment portfolios. The questions have become a "gold standard" in the measure of financial literacy and have been used in different other surveys, including the FINRA National Financial Capability Study $(2009,2012,2015)$ that analyses the financial literacy of American adults (18-65 years old), the SAVE Study 2010 (a longitudinal study of households' financial behaviour in Germany with a special focus on savings and old-age provision), the Canadian Financial Capability Survey (2009) of Canadian adults, and the Survey on Household Income and Wealth (SHIW 2008, SHIW 2010) promoted by the Bank of Italy (Italian national central bank and financial authority) to study the financial behaviour of the Italian households. Previous studies have also considered numeracy and mathematical skills related to financial literacy (Gustman et al. 2012; Remund 2010), and it has been argued that numeracy is a particularly important determinant of economic outcomes (Almenberg and Widmark 2011). However, other researchers (Hung et al. 2009) highlight that numeracy applies more broadly than only to financial issues and thus represents a more basic skill than financial literacy. It should therefore be treated as a distinct construct and not be included in measures of financial literacy. Other specific topics such as knowledge about insurance (Chen and Volpe 1998), knowledge about bank accounts (O’Neil 2003; Mandell 2003; Worthington 2006), and knowledge about methods of payments (FSA 2006; Lyons 2007; Mansfield and Pinto 2008) have also been included in measurements of financial literacy.

\section{Financial Literacy and Retirement Financial Behaviour}

Acknowledging the multidimensionality of the knowledge construct, and also noting that financial services are regarded as complex and cognitively challenging, several studies have documented the behavioural effects on individual interactions with different financial services from simple saving instruments such as bank accounts to complex investment instruments, also including the decision to take loans on mortgage connected to a house purchase.

The majority of these behaviourally oriented studies include measures of objective, or factbased financial literacy (F-BFL). Starting with very general financial behaviour, individuals with low levels of objective financial literacy have been shown to be overrepresented among those without any transaction account (Hogarth et al. 2005) and to have a significantly higher probability of being unbanked (Grimes et al. 2010). Further, F-BFL has been found to be positively related to wealth accumulation (Behrman et al. 2012), likelihood to invest in risky assets and to do it more efficiently (Calvet et al. 2007), and to choice of mortgage and other decisions associated with borrowing (such as refinancing of fixed rate mortgages) (Campbell 2006). 
Focusing specifically on retirement saving, several studies have more specifically demonstrated the impact of level of objective financial literacy on the various phases of retirement financial behaviour: retirement planning, retirement saving, and retirement investment activity. The first phase of retirement planning is heavily affected by level of objective financial literacy. Whereas the vast majority of participants never undertakes any kind of planning activity associated with retirement saving (Lusardi and Mitchell 2007), those high in financial literacy are more likely to have thought about their income after retirement (Lusardi and Mitchell 2007) as well as to have had any documented activity in retirement planning activities (van Rooij et al. 2011). The causality is, however, ambiguous since it is not in general possible to refute the possibility that intending to plan for retirement motivates individuals to increase their financial literacy (Lusardi 2009). Yet, analyses based on differences in US federal mandatory financial education (Lusardi 2009) indicate that individuals exposed to financial education in high school (Bernheim et al. 2001) are more involved in financial planning activities, hence, implying that the causality runs from F-BFL to subsequent financial behaviour such as retirement planning (Lusardi 2009). This does not exclude influences also in the other direction.

The subsequent phase of retirement saving shows evidence of being associated with objective financial literacy. Thus, financial literacy has been found to increase the probability of participating in pre-set retirement plans (Lusardi and Mitchell 2007). The knowledge an individual has about a pension plan has similarly been shown to increase the likelihood of investments in the plan (Hadar et al. 2013) as well as to have an impact on information search and reliance on financial advisors. It has also been found that individuals low in financial literacy rely on recommendations from retirement advisors to a higher extent than individuals high in financial literacy (Carmel et al. 2015).

In the retirement investment phase, differences in the actual investment activity have been shown to vary with level of financial literacy. Thus, individuals high in financial literacy are more likely than individuals low in financial literacy to invest in risky assets when saving for retirement (van Rooij et al. 2011). When comparing numeracy to a more inclusive measure of F-BFL (including familiarity with financial products and concepts), only the latter had a significant impact on risk taking (Almenberg and Dreber 2015).

Some study measures of subjective financial literacy have likewise been found to be linked to financial behaviour. For instance, a US investor survey showed that individuals rating themselves to be knowledgeable about financial product offerings traded more and had a higher degree of international diversification (Graham et al. 2009). Subjective financial literacy has also been associated with various types of responsible financial behaviour, including participation in retirement savings plans (Tang and Baker 2015), and to active choices of mutual funds in retirement savings (Hauff 2006).

\section{The Present Study}

\section{Overview}

Our aim is to investigate the relationships shown in Figure 1. In line with Huston (2010), we first posit that there exists a unitary financial literacy dimension made up of specific financial knowledge in several topical areas. We further posit that this dimension in conjunction with subjective financial literacy influences financial behaviour. Whereas F-BFL may increase the 


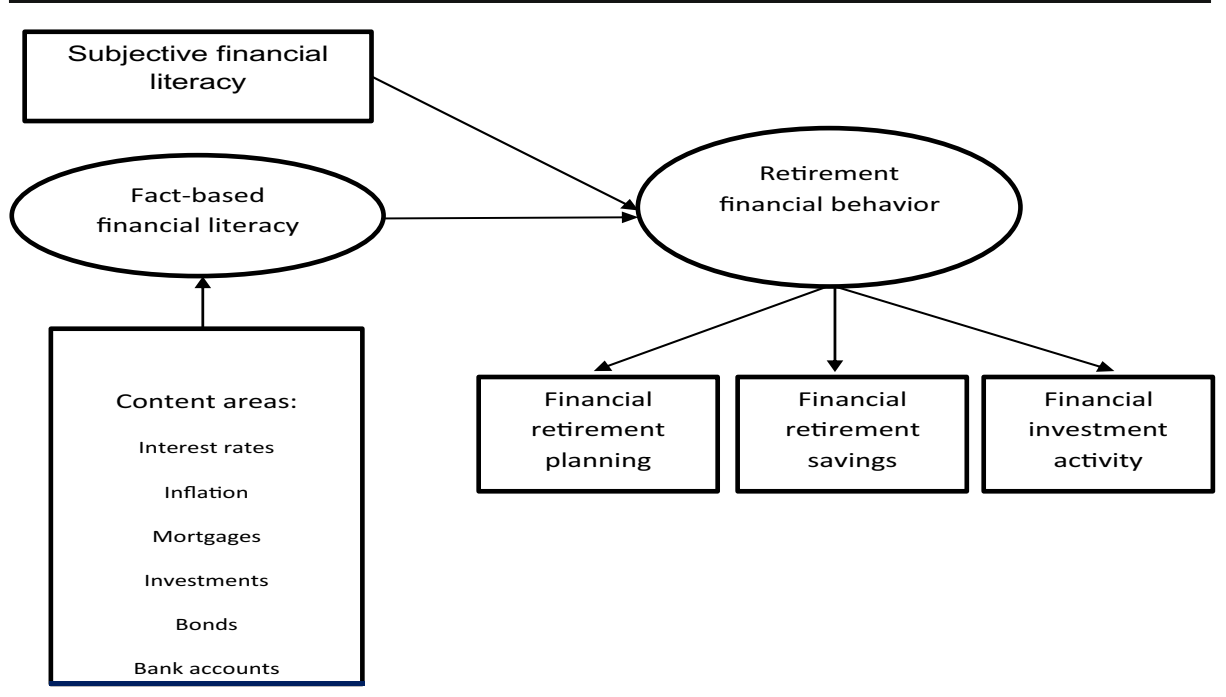

Fig. 1 Relationships investigated in the present study

frequency of reasonable and sound financial behaviours, subjective financial literacy (or confidence) may increase the propensity to at all engage in the behaviours.

In order to cover a wider range of financial knowledge than the 5-question measure (the Big5) used in the bulk of previous research (Huston 2010), we use a new measure of financial literacy that covers more content areas. The measure is developed as part of a research project with the aim of collecting questionnaire data on financial literacy in several different countries. ${ }^{1}$ Our current aim is to counteract the potential weaknesses in previous research linking financial behaviour to financial literacy measured as the Big5. The main problem with the Big5 are that some of the contents of the questions (inflation, interest rates, mortgages, bond pricing, and diversification) may be too general, and the number of questions is too few to fully explain individual variation in specific financial behaviours. In a study by Fernandes et al. (2014), the commonly used Big5 was expanded into a 13-item measure by adding questions used in previous research. Our new measure of financial literacy is instead developed based on IRT following Knoll and Houts (2012). To further improve the questions ability to discriminate between individuals with different levels of financial literacy, we included questions that vary in difficulty. This is hence one advantage of our measure compared with that of Knoll and Houts (2012). In addition, we assess the uni-dimensionality of the final scale.

We first determine whether we measure a single dimension of F-BFL. When this is not refuted by the results, we continue by using uni-dimensional IRT (de Ayala 2009; Knoll and Houts 2012) to select a set of questions that is optimal in measuring the financial literacy dimension. In order to determine whether our measure yields the same pattern of results as found in previous research, we make comparisons with the Big5 financial literacy questions (included in the survey questionnaire) as well as investigate relations to several socioeconomic variables describing our sample. Finally, we investigate how our measure of objective financial literacy and a self-report measure of subjective financial literacy are related to questionnaire

\footnotetext{
${ }^{1}$ The research project is initiated by the Consumer Finance Research Center (CFRC) coordinated by researchers from the University of Rome 'Tor Vergata' including contributions of researchers from France, Spain, Sweden, and the United Kingdom. The aim of the project is to develop an improved measure of financial literacy and to investigate the role of financial literacy for different financial behaviors.
} 
measures of the three stages of financial retirement planning, financial retirement savings, and financial investment activities.

\section{Method}

\section{Survey Questionnaire}

An invention of topics relevant to determine level of financial literacy constitutes our starting point for the construction of new questions. The financial topics included interest rates, inflation, mortgage, investments, bonds, bank accounts, payments, savings and investments, and loans and debts. The decision to use a broad spectrum of financial topics was driven by the assumption that people tend to develop financial knowledge and skills according to their financial needs. Thus, people who have never taken up loans may be less knowledgeable about loans and debts than people who have experiences of borrowing. Likewise, if people manage their wealth and make investment decisions, they will be more likely to be financially knowledgeable about investing than those who do not. A broad range of topics should therefore guarantee a high content validity such that the measure of financial literacy neither overestimates nor underestimates individuals' financial literacy due to a biased content selection.

In different areas of financial knowledge, it is essential that fact-based questions are of comparable difficulty. Otherwise, the resulting scale would misrepresent areas that in this respect substantially differ from the others. Furthermore, questions should not be too difficult or easy to provide the best discrimination between individuals' knowledge. In order to comply with these two requirements, five questions varying from low to high were included in each content area. The different difficulty levels were initially judged by one of the co-authors (GN). The two-parameter IRT then makes possible to select items across knowledge areas with equal and appropriate difficulty. Answers to true/false and multiple-choice questions measuring FBFL were categorized as either correct or incorrect with "do not know" and "rather not say" treated as incorrect.

The questions in the survey were translated from Italian to English and then from English to Swedish. Sixty-four questions were asked about demographics and different behavioural measures and 50 questions about the different topics related to financial literacy (one question had to be omitted due to a translation error, thus leaving 49 questions) (see Supplementary Material).

\section{Sample and Procedure}

Data were collected through CINT, a marketing research company, hosting a number of worldwide web panels. CINT does not manage their own panel; they pool resources from both self-recruited $(\approx 85 \%)$ and probability $(\approx 15 \%)$ samples. A sample of Swedish citizens, both men and women, between the ages of 18 and 65 , were invited to take part in the study.

The number of participants included in the main analyses was 551 of a total of 637 . We excluded participants who responded too uniformly (responded only or mostly "do not know") or failed to answer trivially easy questions ("Do you currently have a bank account?"). The sample was approximately representative of the Swedish population as compared with the official statistics (Table 1). 
Table 1 Description of sample representativeness (gender, age, income, and educational attainment) compared with the Swedish population. Source: Authors' calculations

\begin{tabular}{lll}
\hline & Sweden $^{\mathrm{a}}$ & Sample \\
\hline Women (\%) & 49.94 & 50.55 \\
Age (mean years) & 41.24 & $41-45$ \\
Income (mean net monthly income in SEK) & $22,991^{\mathrm{b}}$ & $15,000-22,000$ \\
Educational attainment (university degree, \%) & 22.86 & 30.6 \\
\hline
\end{tabular}

a Statistics Sweden (2015): www.statistikdatabasen.scb.se/pxweb/en/ssd/

${ }^{\mathrm{b}}$ In the age range $20-64$

\section{Results}

\section{Dimensionality Analysis}

An assumption underlying financial literacy measures is that responses to the questionnaire questions load on a single dimension (Knoll and Houts 2012). Hence, we assessed dimensionality by means of a confirmatory factor analysis of tetrachoric correlations using weighted mean and variance adjusted least-squares (WLSMV) estimation. The analyses were conducted in Mplus version 7 (Muthén and Muthén 1998-2012).

Our initial results showed an acceptable goodness of fit for a one-factor model, RMSEA = $0.05, \mathrm{CFI}=0.86, \mathrm{TLI}=0.85, \mathrm{WRMR}=1.60$. Yet, the model fit was improved by specifying a model with ten correlated factors corresponding to each specific topic, RMSEA $=0.03, \mathrm{CFI}=$ $0.92, \mathrm{TLI}=0.91, \mathrm{WRMR}=1.29$. Since a critical ratio of $c^{2} / d f=3.84$ improvement in goodness of fit was not exceeded, we assume that the questions are locally independent, which implies that replies to a specific question are only related to one underlying latent dimension and no other confounding latent dimensions. Hence, we conclude that the 49 questionnaire questions load on one dimension. A ten-factor model could however also be chosen but the one-factor model is more appropriate given our aim of constructing a single scale measuring F-BFL. We therefore proceed to construct a reliable scale by selecting appropriate questions.

\section{Item Response Theory}

IRT was developed for psychometric analyses of data from ability tests (de Ayala 2009). Based on IRT, we model the probability of a correct response to a question in the survey questionnaire as a mathematical function of participants' degree of financial literacy, considered as a latent dimension, and parameters characterizing the questions measuring the latent dimension. Although the model may include one or several item parameters, we choose two parameters that estimate difficulty of the item and how accurate it discriminates between high and low levels on the latent dimension. The probability $(\operatorname{Pr})$ of a correct response $\left(x_{j}=1\right)$, given the latent dimension $(\theta)$, the two-item parameter discrimination $\left(\alpha_{j}\right)$, and difficulty $\left(\delta_{j}\right)$ is modeled as

$$
\operatorname{Pr}\left(x_{j}=1 \mid \theta, \alpha_{j} \delta_{j}\right)=\frac{e^{\alpha_{j}\left(\theta-\delta_{j}\right)}}{1+e^{\alpha_{j}\left(\theta-\delta_{j}\right)}}
$$

We fit the two-parameter logistic IRT model to correctness of answers to the 49 questions using STATA version 14.1. Both parameter values and graphical plots of the initial result were 
inspected in order to determine how each question was able to discriminate between high and low levels of financial literacy $(\alpha)$, and how difficult each question was $(\delta)$. Several questions had a low level of discrimination $(\alpha<1)$ which means that the question does not adequately measure the latent dimension of financial literacy $(\theta)$. Similarly, given different levels of difficulty, some questions were too difficult whereas others where too easy. This will produce a non-satisfactory probability function. There was also some redundancy in terms of two or more questions having nearly identical discrimination and difficulty parameter values. Based on these criteria, we included 16 items. Topic, question, discrimination (parameter $\alpha$ ), and difficulty (parameter $\delta$ ) are given in Table 2. Nine of the ten topics are represented by at least one question and in the case of two or more questions per topic, these have been chosen with the largest variation in difficulty. The topic of payments did not have any questions that discriminated adequately and four of the five questions seemed to be too easy.

An item characteristic curve (ICC) is the logistic regression of the probability of a correct response on the estimated degree of financial literacy $(\theta)$. As can be seen in Figure 2, all of the included questions show an S-shaped regression curve with different levels of difficulty $(\delta)$ ranging from -0.81 to 1.50 . The slopes show that most questions discriminate between high and low levels of ability (ideally $\alpha \geq 1$ ).

In Figure 3, we plot an item information function (IIF) showing the amount of information each question provides in estimating financial literacy. Each question provides the maximum amount of information at its estimated level of difficulty $(\delta)$ and the height of each curve is proportional to the item discrimination $(\alpha)$. In order to summarize how much information the scale provides, we plot in Figure 4 a test information function (TIF) which is the sum of all included IIF. As can be seen, the TIF has a peak value at approximately $\theta=0$ which means that the 16 items are best at discriminating an average level of financial literacy. The increase in standard error with both higher and lower levels of difficulty indicates that discrimination is worse at either extremes of financial literacy.

Final questions were selected based on visual inspections of the S-curves, the item discrimination $(\alpha)$, and the difficulty $(\delta)$ parameters. Cutoffs and ranges for discrimination $(\alpha)$ are arbitrary but values between one and two are considered acceptable by most recommendations. Since the difficulty parameter for a combination of both high and low difficulties may be suitable with \pm 0.5 considered medium difficulty (for further reference, see de Ayala 2009). For example, in our case, the questions pertaining to interest rates (in Supplementary Material) indicate that there is only one question that has a discrimination parameter $(\alpha)$ of at least close to one and that is the third question (INT3). Furthermore, the difficulty parameter of the third question (INT3) shows that it is a rather easy question with a value of -0.39 . We also aimed to have achieved variation within each topic without introducing redundancy.

\section{Validation}

Based on the parameter estimates for the 16 questions constituting the new F-BFL scale, we obtained an empirical Bayes means of latent variable measure of each participant's financial literacy $(\mathrm{M}=0, \mathrm{SD}=0.91, \mathrm{~min} / \mathrm{max}=-1.81 / 2.24$, Skewness $=0.16, \mathrm{Kurtosis}=2.58)$. We then correlated the scale with self-reported financial literacy (a 7-point subjective rating scale ranging from "low" to "high") and with the sum of correct responses to the five questions in the Big5 (Lusardi and Mitchell 2007), which were included in the questionnaire (questions INT1, INF1, MRG1, INV1, and BND1, see Table 2). We observed a significant positive correlation with both measures: $r(502)=0.43, p<0.001$, and $r(552)=0.78, p<0.001$. Note 
Table 2 Topics, questions, and estimated discrimination $(\alpha)$ and difficulty $(\delta)$

\begin{tabular}{|c|c|c|c|}
\hline Topic & Question & $\begin{array}{l}\text { Discrimination } \\
(\alpha)\end{array}$ & $\begin{array}{l}\text { Difficulty } \\
(\delta)\end{array}$ \\
\hline $\begin{array}{l}\text { Interest rates } \\
\quad \text { (INT3) }\end{array}$ & $\begin{array}{l}\text { Suppose you had } \$ 100 \text { in a savings account and the interest } \\
\text { rate was } 2 \% \text { per year. After } 5 \text { years, how much do you } \\
\text { think you would have in the account if you left the money } \\
\text { to grow? }\end{array}$ & 0.90 & -0.40 \\
\hline $\begin{array}{l}\text { Inflation } \\
\qquad(\mathrm{INF} 1)\end{array}$ & $\begin{array}{l}\text { Imagine that the interest rate on your savings account was } 1 \% \\
\text { per year and inflation was } 2 \% \text { per year. After } 1 \text { year, how } \\
\text { much would you be able to buy with the money in this } \\
\text { account? }\end{array}$ & 2.04 & -0.57 \\
\hline $\begin{array}{l}\text { Inflation } \\
\text { (INF4) }\end{array}$ & $\begin{array}{l}\text { If your bank will pay } 4 \% \text { a year on your } \$ 100 \text { balance saving } \\
\text { account, how much inflation do you expect if you think } \\
\text { you will save your purchase power after } 2 \text { years? }\end{array}$ & 1.92 & -0.31 \\
\hline $\begin{array}{l}\text { Mortgage } \\
\quad(\text { MRG2) }\end{array}$ & $\begin{array}{l}\text { Comparing with a } 15 \text {-year mortgage, if you want to reduce } \\
\text { the total interest paid over the life of a loan, which of the } \\
\text { following mortgage do you have to prefer? }\end{array}$ & 1.41 & -0.23 \\
\hline $\begin{array}{l}\text { Mortgage } \\
\text { (MRG3) }\end{array}$ & $\begin{array}{l}\text { In a } 15 \text {-year mortgage which of the following options will } \\
\text { minimize the total interest paid over the life of the loan? }\end{array}$ & 1.08 & 0.55 \\
\hline $\begin{array}{l}\text { Investments } \\
\text { (INV1) }\end{array}$ & $\begin{array}{l}\text { Buying a single company's stock usually provides a safer } \\
\text { return than a stock mutual fund. }\end{array}$ & 1.76 & -0.44 \\
\hline $\begin{array}{l}\text { Investments } \\
\quad \text { (INV2) }\end{array}$ & $\begin{array}{l}\text { Compared with an investment in stocks, the risk in investing } \\
\text { in mutual funds is... }\end{array}$ & 1.92 & 0.01 \\
\hline $\begin{array}{l}\text { Investments } \\
\quad \text { (INV4) }\end{array}$ & $\begin{array}{l}\text { Which of the following investment options fits well for an } \\
\text { investor that wants to double his money in a very short } \\
\text { term? }\end{array}$ & 1.35 & 0.40 \\
\hline Bonds (BND4) & Buying a bond is a good strategy if you think that... & 1.29 & 1.28 \\
\hline $\begin{array}{l}\text { Bank accounts } \\
\quad \text { (BCC4) }\end{array}$ & Which of the following scenarios do NOT fit with e-banking? & 0.94 & -0.62 \\
\hline $\begin{array}{l}\text { Savings and } \\
\text { investments } \\
\text { (SIV1) }\end{array}$ & $\begin{array}{l}\text { Ignoring the case of default of the issuer, which of the } \\
\text { following investment products guarantees the } \\
\text { reimbursement of the invested capital? }\end{array}$ & 1.87 & 0.09 \\
\hline $\begin{array}{l}\text { Savings and } \\
\text { investments } \\
\text { (SIV3) }\end{array}$ & $\begin{array}{l}\text { Which is the standard measure for the default risk } \\
\text { of a bond issuer? }\end{array}$ & 1.34 & 1.36 \\
\hline $\begin{array}{l}\text { Savings and } \\
\text { investments } \\
\text { (SIV4) }\end{array}$ & $\begin{array}{l}\text { If the same company issues short-term and a long-term bond, } \\
\text { typically the interest rate of the long-term bond is... }\end{array}$ & 1.18 & 1.50 \\
\hline $\begin{array}{l}\text { Loans and debts } \\
\text { (LDB4) }\end{array}$ & In a mortgage, if the value of the collateral is higher... & 1.42 & 0.11 \\
\hline $\begin{array}{l}\text { Retirement and } \\
\text { planning } \\
\text { (RAP3) }\end{array}$ & $\begin{array}{l}\text { Do you think that the performance of financial markets } \\
\text { can affect the performance of a pension fund? }\end{array}$ & 1.44 & 0.78 \\
\hline $\begin{array}{l}\text { Retirement and } \\
\text { planning } \\
\text { (RAP4) }\end{array}$ & $\begin{array}{l}\text { Feeding a pension fund with } \$ 10,000 \text { a year for } 10 \text { years } \\
\text { is equal to feed } \$ 5,000 \text { a year for } 20 \text { years }\end{array}$ & 1.21 & 1.15 \\
\hline
\end{tabular}

however that the correlation between our scale and Big5 is inflated because two questions (INF1 and INV1) overlap.

We also investigated whether our financial literacy scale has the relationships with socioeconomic factors that have been found in previous research employing other measures. As can be seen in Figure 5, F-BFL first increases with age, then decreases except for the deviating higher value in the 61-65-years age group. A positive relationship with age has been observed in several studies (Lusardi et al. 2010), focusing primarily on the low literacy of young people (hence making them more vulnerable). Our results are similar to that of other research which 


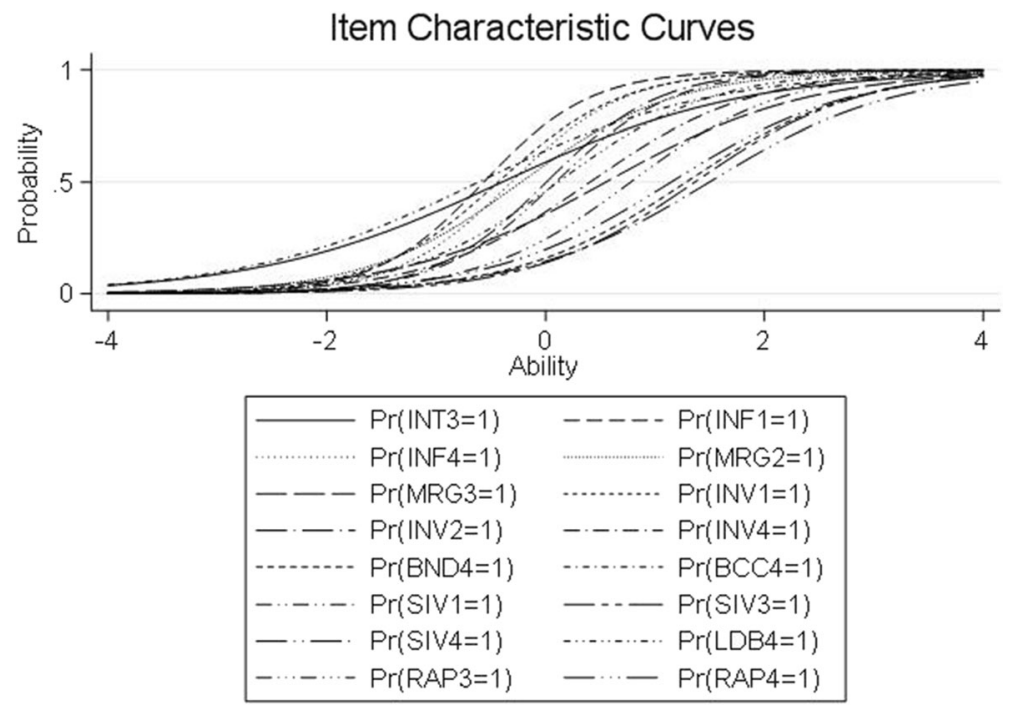

Fig. 2 Item Characteristic Curves (ICC) for the 16 items included in the fact-based financial literacy scale

found that a non-linear relationship exists between age and literacy; e.g., Lusardi and Mitchell (2014) found that people above 65 years old had a lower financial literacy score. This inverted U-shaped relation has been proposed to reflect an increasing experience with financial matters when people grow older and subsequently deteriorating cognitive capacity and/or reduced interest explaining the decline.

We also found gender differences. Men $(\mathrm{M}=4.39, \mathrm{SD}=1.39)$ rated themselves significantly higher $[t(496)=6.24, p=<0.001]$ on subjective financial literacy compared with women $(\mathrm{M}=3.60, \mathrm{SD}=1.44)$, and men $(\mathrm{M}=0.35, \mathrm{SD}=0.88)$ were significantly higher $[t(496)=$ 9.23, $p=<0.001]$ on F-BFL compared with women $(\mathrm{M}=-0.32, \mathrm{SD}=0.80)$. That women

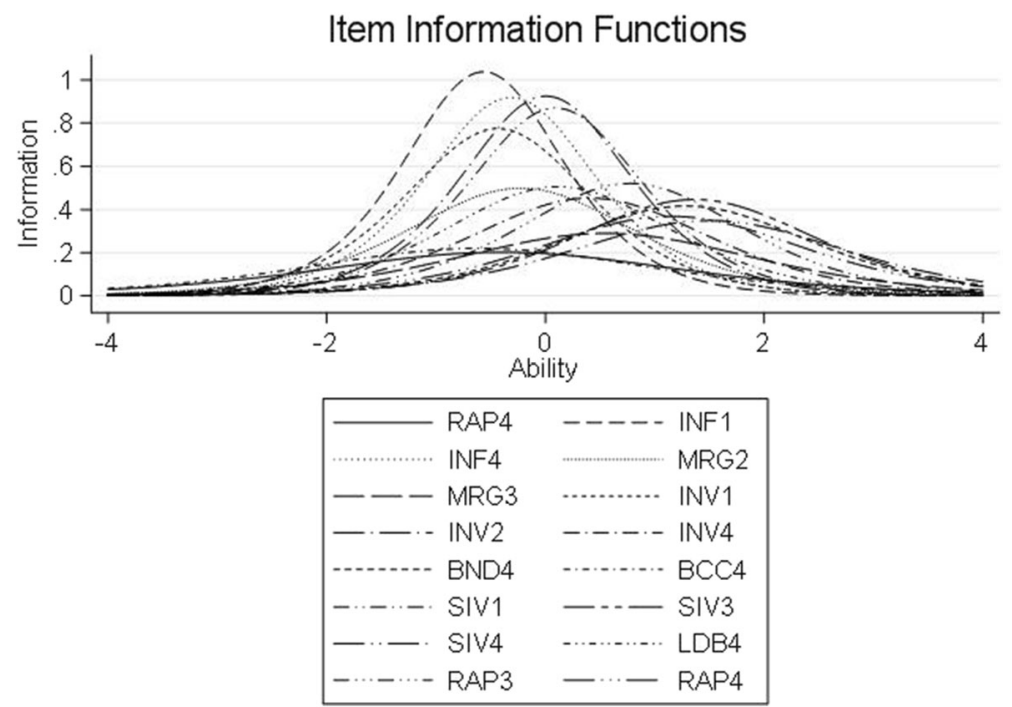

Fig. 3 Item Information Functions (IIF) for the 16 items in the fact-based financial literacy scale 


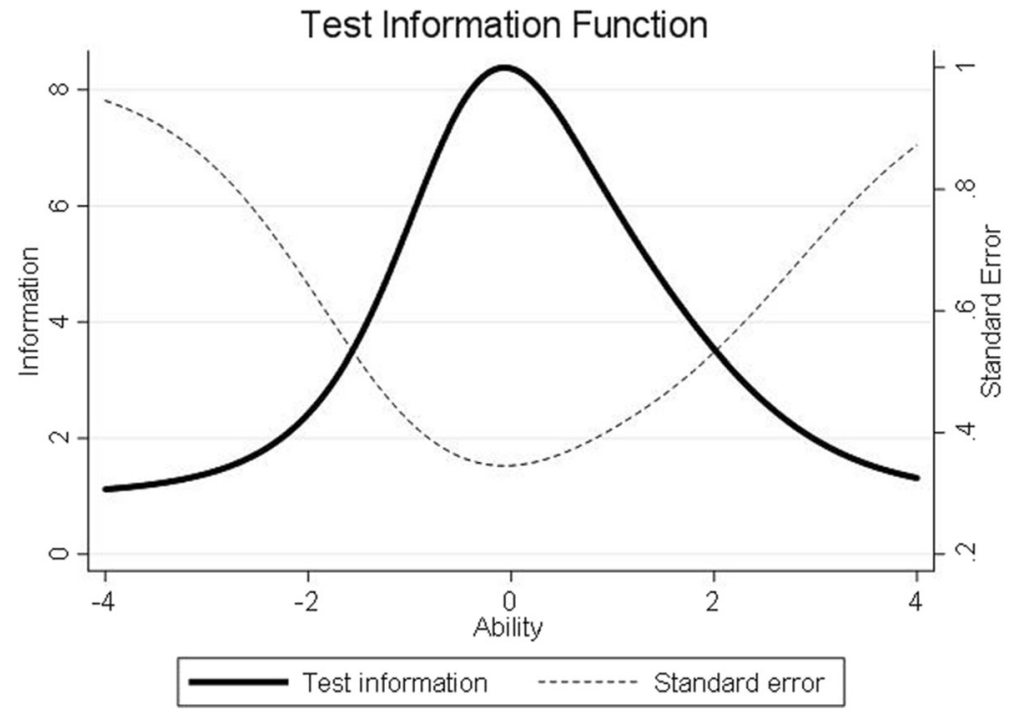

Fig. 4 Test Information Function (TIF) showing the precision of the fact-based financial literacy scale at different levels of ability

score lower on F-BFL measure is documented (Lusardi \& Mitchell 2008; Bucher-Koenen et al. 2014).

The evidence that financial literacy has a positive impact on wealth accumulation is abundant (e.g., Lusardi and Mitchell 2007; van Rooij et al. 2012). But wealth may also increase financial literacy (Delavande et al. 2008; Monticone 2010) since having personal financial experiences is an opportunity or requirement to learn which may result in a higher FBFL (Hilgert et al. 2003). In our data, there was a significant relationship between income and

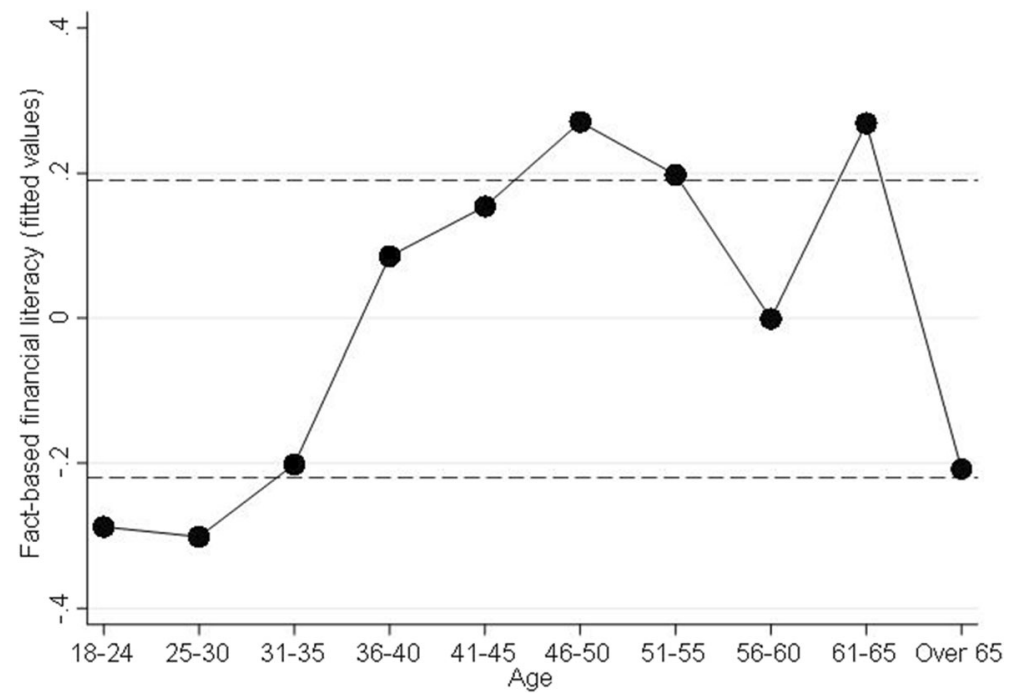

Fig. 5 Scores on the fact-based financial literacy scale for ten different age groups 
self-reported subjective financial literacy, $r(461)=0.21, p<0.001$, as well as between income and F-BFL, $r(502)=0.27, p<0.001$.

\section{The Relationship to Retirement Financial Behaviour}

This section analyses how the self-report measures of different phases of retirement financial behaviour (Fig. 1) are related to our F-BFL measure and self-rated financial literacy (S-RFL). The behavioural measures are the initial retirement planning stage, the actual setting aside of money for the purpose of retirement income, retirement savings, and retirement investments (behaviour related to investment management such as asset re-allocation). In the following analyses, we also compare F-BFL to the Big5 to determine whether it has stronger relationships to the behavioural measures.

\section{Retirement Planning}

To the question "Have you ever tried to figure out how much you need to save for retirement", 121 participants answered they had and 391 participants that they had not (39 missing). This corresponds to previous results showing a low proportion of retirement planners (Lusardi \& Mitchell 2008). The results of a logistic regression analysis are shown in Table 3. That a F-BFL measure has a significant impact is consistent with several previous studies (van Rooij et al. 2012). If our new scale is an improved measure of financial literacy, one should expect that it would account for more variance than the Big5 in models of the relationship with retirement saving behaviours. In Model 1, the coefficient for the Big5 is significant but not in Model 3 where both the new scale of F-BFL and S-RFL have significance coefficients. In Model 2, the coefficients associated with F-BFL and S-RFL are both significant. In Model 4, these coefficients remain significant when age, gender, education, and income are added.

The significant impact of S-RFL needs some further comments. Performing any kind of retirement planning is not easy - not even attempting to assess the present level of retirement savings is not a straight-forward. For the typical Swedish individual, retirement planning entails summing up savings from (at least) three sources: state income pensions (including a portfolio where the individuals themselves make investments), work-related pensions (with often one savings portfolio per previous employer), and private savings. Performing the retirement planning activities therefore has several both economic and psychological barriers (van Rooij et al. 2012). It is understandable then that subjective financial literacy or confidence has an impact on engagement in these activities.

\section{Retirement Saving}

An affirmative answer to the question "Are you setting aside any money for the purpose of your retirement?" was given by 288 participants, whereas 234 answered no (39 missing). An additional logistic regression reported in Table 4 shows that the Big5 has a significant coefficient when entered alone but not when F-BFL and S-RFL are entered. However, only the coefficient for F-BFL is significant and remains significant when age, gender, education, and income are entered. It may be noted that income is also significant.

One should expect that the retirement saving phase is related to the planning process since forming an accumulation plan would result in a retirement savings portfolio. The fact that we 
Table 3 Logistic regression analyses of determinants of answers to the question about retirement planning ("Have you ever tried to figure out how much you need to save for retirement?" coded $0=$ no, $1=$ yes)

\begin{tabular}{|c|c|c|c|c|c|c|c|c|}
\hline & \multicolumn{2}{|l|}{ Model 1} & \multicolumn{2}{|c|}{ Model 2} & \multicolumn{2}{|l|}{ Model 3} & \multicolumn{2}{|c|}{ Model 4} \\
\hline & $\beta$ & SE & $\beta$ & SE & $\beta$ & SE & $\beta$ & SE \\
\hline Big5 & $0.40^{* * *}$ & 0.08 & & & -0.19 & 0.15 & & \\
\hline S-RFL & & & $0.54^{* * *}$ & 0.10 & $0.54^{* * *}$ & 0.10 & $0.55^{* * *}$ & 0.11 \\
\hline F-BFL & & & $0.49^{\text {****}}$ & 0.14 & $0.63^{* * * *}$ & 0.21 & $0.40^{* * *}$ & 0.17 \\
\hline Age & & & & & & & $0.37^{* *}$ & 0.05 \\
\hline Gender & & & & & & & -0.02 & 0.28 \\
\hline Education & & & & & & & -0.10 & 0.13 \\
\hline Income & & & & & & & $0.30^{*}$ & 0.08 \\
\hline Pseudo-R ${ }^{2}$ & \multicolumn{2}{|l|}{$0.03^{* * *}$} & \multicolumn{2}{|l|}{$0.10^{* * *}$} & \multicolumn{2}{|l|}{$0.10^{* * * *}$} & \multicolumn{2}{|l|}{$0.14^{* * * *}$} \\
\hline Wald & \multicolumn{2}{|l|}{$12.81,0.0003$} & \multicolumn{2}{|c|}{$43.28,<0.0001$} & \multicolumn{2}{|c|}{$44.49,<0.0001$} & \multicolumn{2}{|c|}{$49.29,<0.0001$} \\
\hline
\end{tabular}

find a weaker connection with S-RFL suggests that actual saving is more related to fact-based knowledge of mutual funds and other instruments.

\section{Retirement Investments}

In the logistic regression analyses reported in Table 5, the results are similar in showing that the Big5 has a significant coefficient only when entered alone and that F-BFL is significant in all other models accounting for the percentages of participants who reported that they invest in stocks (68\%), mutual funds (74\%), and bonds (62\%). This is consistent with previous studies, where the costs of information search and information processing about risky investments such as stocks are reduced when level of financial literacy increases (Vissing-Jorgensen 2004). SRFL is only significant for investments in stocks. Perhaps this reflects the existence of a

Table 4 Logistic regression analyses of determinants of answers to the question about retirement saving ("Are you setting aside any money for the purpose of your retirement?" coded $0=$ no, $1=$ yes)

\begin{tabular}{|c|c|c|c|c|c|c|c|c|}
\hline & \multicolumn{2}{|l|}{ Model 1} & \multicolumn{2}{|l|}{ Model 2} & \multicolumn{2}{|c|}{ Model 3} & \multicolumn{2}{|c|}{ Model 4} \\
\hline & $\beta$ & SE & $\beta$ & SE & $\beta$ & $\mathrm{SE}$ & $\beta$ & SE \\
\hline Big5 & $0.39^{* * *}$ & 0.07 & & & -0.23 & 0.12 & & \\
\hline S-RFL & & & 0.20 & 0.07 & 0.20 & 0.07 & 0.16 & 0.08 \\
\hline F-BFL & & & $0.51^{* * * *}$ & 0.12 & $0.68^{* * * *}$ & 0.18 & $0.46^{* * * *}$ & 0.14 \\
\hline Age & & & & & & & -0.03 & 0.05 \\
\hline Gender & & & & & & & -0.17 & 0.24 \\
\hline Education & & & & & & & -0.21 & 0.11 \\
\hline Income & & & & & & & $0.80^{* * *}$ & 0.08 \\
\hline Pseudo-R ${ }^{2}$ & $0.03^{* * *}$ & & $0.06^{* * *}$ & & $0.06^{* * * *}$ & & $0.13^{* * *}$ & \\
\hline Wald & $18.50,<0.000$ & & $35.84,<$ & 001 & 37.43 & 001 & 61.24 & 001 \\
\hline
\end{tabular}


Table 5 Logistic regression analyses of determinants of answers to the question about retirement investments; "When investing, do you consider the following...," coded $0=$ no, $1=$ yes

\begin{tabular}{|c|c|c|c|c|c|c|c|c|}
\hline & \multicolumn{2}{|l|}{ Model 1} & \multicolumn{2}{|c|}{ Model 2} & \multicolumn{2}{|c|}{ Model 3} & \multicolumn{2}{|l|}{ Model 4} \\
\hline & $\beta$ & SE & $\beta$ & SE & $\beta$ & SE & $\beta$ & SE \\
\hline \multicolumn{9}{|l|}{ Stocks ${ }^{\mathrm{a}}$} \\
\hline Big5 & $0.66^{* * * *}$ & 0.08 & & & -0.03 & 0.14 & & \\
\hline S-RFL & & & $0.28^{*}$ & 0.08 & $0.28^{*}$ & 0.08 & 0.25 & 0.09 \\
\hline F-BFL & & & $0.85^{* * * * *}$ & 0.14 & $0.87^{* * * *}$ & 0.20 & $0.89^{* * *}$ & 0.17 \\
\hline Age & & & & & & & $-0.52^{* * *}$ & 0.05 \\
\hline Gender & & & & & & & 0.16 & 0.25 \\
\hline Education & & & & & & & -0.19 & 0.12 \\
\hline Income & & & & & & & 0.18 & 0.08 \\
\hline Pseudo- $R^{2}$ & $0.07^{* * * *}$ & & $0.14^{* * * *}$ & & $0.14^{* * * *}$ & & $0.17^{* * * *}$ & \\
\hline Wald & $39.22,<$ & 001 & 61.41, & 001 & 61.45, & 001 & $62.05,<$ & \\
\hline \multicolumn{9}{|l|}{ Mutual funds $\mathrm{s}^{\mathrm{b}}$} \\
\hline Big5 & $0.61^{* * * *}$ & 0.08 & & & -0.02 & 0.13 & & \\
\hline S-RFL & & & -0.01 & 0.08 & -0.01 & 0.08 & -0.04 & 0.08 \\
\hline F-BFL & & & $0.78^{* * * *}$ & 0.14 & $0.79^{* * * *}$ & 0.21 & $0.81^{* * * *}$ & 0.16 \\
\hline Age & & & & & & & $-0.29^{*}$ & 0.05 \\
\hline Gender & & & & & & & $-0.27^{*}$ & 0.26 \\
\hline Education & & & & & & & 0.07 & 0.12 \\
\hline Income & & & & & & & $0.33^{*}$ & 0.08 \\
\hline Pseudo-R ${ }^{2}$ & $0.06^{* * * *}$ & & $0.09^{* * * *}$ & & $0.09^{* * * *}$ & & $0.10^{* * * *}$ & \\
\hline Wald & $34.36,<$ & 001 & 40.69 & 001 & 40.66 & 001 & $42.76,<$ & 01 \\
\hline \multicolumn{9}{|l|}{ Bonds $^{\mathrm{c}}$} \\
\hline Big5 & $0.69^{* * * *}$ & 0.09 & & & -0.01 & 0.14 & & \\
\hline S-RFL & & & 0.10 & 0.09 & 0.10 & 0.09 & 0.08 & 0.09 \\
\hline F-BFL & & & $0.71^{* * * * *}$ & 0.14 & $0.72^{\text {**** }}$ & 0.20 & $0.60^{* * * *}$ & 0.16 \\
\hline Age & & & & & & & 0.08 & 0.05 \\
\hline Gender & & & & & & & $0.33^{*}$ & 0.27 \\
\hline Education & & & & & & & 0.18 & 0.13 \\
\hline Income & & & & & & & -0.13 & 0.08 \\
\hline Pseudo- $\mathrm{R}^{2}$ & $0.07^{* * * *}$ & & $0.09^{* * * *}$ & & $0.09^{* * * *}$ & & $0.10^{* * * *}$ & \\
\hline Wald & $31.71,<$ & 001 & 36.89 & 001 & 36.91, & 001 & $37.85,<$ & 001 \\
\hline
\end{tabular}

${ }^{*} p<0.05$

*** $p<0.01$

**** $p<0.001$

${ }^{\text {a }}$ Yes $=226$, No $=226$, Do not know $=98$, missing $=9$

${ }^{\mathrm{b}}$ Yes $=324$, No $=152$, Do not know $=65$, missing $=10$

${ }^{\mathrm{c}}$ Yes $=142$, No $=264$, Do not know $=136$, missing $=9$

psychological barrier when the level of risk is perceived to be high. The coefficient for F-BFL was still significant when controlling for age, gender, education, and income.

Both F-BFL and S-RFL were furthermore related to willingness to take investment risks ("Thinking of your financial investments, how willing are you to take risks"?) rated on a 7-step numerical scale ranging from low risk $(=1)$ to high risk $(=7)$, and S-RFL related to satisfaction with the current financial situation ("Looking at your overall personal financial situation [income, debts, savings, investments, etc.], are you satisfied or do you think you need to be worried about the future?") rated on a 10 -step numerical scale ranging from worried (=1) to satisfied $(=10)$. The measurement of risk $(\mathrm{M}=3.34, \mathrm{SD}=1.67)$ showed some positive skew $(0.22)$ and negative kurtosis $(-0.80)$ implying that participants were uniformly less likely to 
take on financial risk. The measurement of satisfaction $(\mathrm{M}=6.64, \mathrm{SD}=2.83)$ indicated that participants were leaning towards higher satisfaction (Skew $=-0.16)$, although participants scoring higher or lower, i.e., more satisfied (10) versus more worried (1), were approximately equally common (Kurtosis $=-1.13$ ). The results for Ordinary Least Squares (OLS) regression analyses shown in Table 6 demonstrate that F-BFL and S-RFL accounts for more variance than the Big5 in risk taking, but for satisfaction only S-RFL does. A significant positive effect of income is observed for the ratings of satisfaction, and so is a negative effect of age. The latter result would imply that the older the individual gets, the less satisfied with the current financial situation he or she is.

\section{Conclusion}

Our study investigated how F-BFL (primarily financial knowledge in different contents areas, see Table 1) as well as self-reported financial literacy influences stages of retirement financial behaviour. The main findings are that F-BFL has a significant impact on all three stages of retirement planning, retirement savings activities, and retirement investment management, however, with the most marked impact on the investment management phase (including the choice of financial instruments). This is consistent with prior findings of studies separately investigating these stages (Lusardi and Mitchell 2007; van Rooij et al. 2011) and taken together, it provides the important insight that financial literacy makes a difference no matter if the current objective of the individual is to plan for the income stream after retirement, to

Table 6 OLS regression analyses of ratings of risk taking and satisfaction with current investments

\begin{tabular}{|c|c|c|c|c|c|c|c|c|c|c|c|c|}
\hline & \multicolumn{3}{|c|}{ Model 1} & \multicolumn{3}{|c|}{ Model 2} & \multicolumn{3}{|l|}{ Model 3} & \multicolumn{3}{|l|}{ Model 4} \\
\hline & $\beta$ & SE & $\mathrm{T}$ & $\beta$ & SE & $\mathrm{T}$ & $\beta$ & SE & $\mathrm{t}$ & $\beta$ & $\mathrm{SE}$ & $t$ \\
\hline \multicolumn{13}{|l|}{ Risk taking } \\
\hline Big5 & $0.33^{* * * *}$ & 0.06 & 7.38 & & & & 0.10 & 0.09 & 1.51 & & & \\
\hline S-RFL & & & & $0.33^{* * * *}$ & 0.05 & 7.14 & $0.33^{* * *}$ & 0.05 & 7.11 & $0.29^{* * *}$ & 0.06 & 6.13 \\
\hline F-BFL & & & & $0.23^{* * * *}$ & 0.09 & 4.99 & $0.30^{*}$ & 0.13 & 2.34 & $0.15^{*}$ & 0.10 & 3.05 \\
\hline Age & & & & & & & & & & -0.06 & 0.03 & -1.17 \\
\hline Gender & & & & & & & & & & $0.17^{*}$ & 0.16 & 3.49 \\
\hline Education & & & & & & & & & & 0.03 & 0.08 & 0.78 \\
\hline Income & & & & & & & & & & $0.15^{*}$ & 0.05 & 3.09 \\
\hline$R_{\text {adj }}^{2}$ & $0.11^{* * *}$ & & & $0.22^{* * * *}$ & & & $0.23^{* * *}$ & & & $0.26^{* * *}$ & & \\
\hline$\Delta R^{2}$ & & & & 0.11 & & & 0.01 & & & 0.03 & & \\
\hline \multicolumn{13}{|l|}{ Satisfaction } \\
\hline Big5 & $0.29^{* * * *}$ & 0.09 & 6.90 & & & & 0.06 & 0.14 & 0.96 & & & \\
\hline S-RFL & & & & $0.33^{* * * *}$ & 0.09 & 7.09 & $0.33^{* * *}$ & 0.09 & 7.03 & $0.28^{* * * *}$ & 0.09 & 6.31 \\
\hline F-BFL & & & & $0.14^{* *}$ & 0.14 & 3.04 & 0.10 & 0.21 & 1.40 & $0.12^{*}$ & 0.15 & 2.54 \\
\hline Age & & & & & & & & & & $-0.18^{* * *}$ & 0.05 & -4.10 \\
\hline Gender & & & & & & & & & & -0.08 & 0.24 & -1.69 \\
\hline Education & & & & & & & & & & -0.05 & 0.12 & -1.17 \\
\hline Income & & & & & & & & & & $0.44^{* * *}$ & 0.08 & 9.39 \\
\hline$R_{\text {adj }}^{2}$ & $0.08^{* * * *}$ & & & $0.17^{* * *}$ & & & $0.17^{* * *}$ & & & $0.31^{* * * *}$ & & \\
\hline$\Delta R^{2}$ & & & & 0.09 & & & 0.00 & & & 0.14 & & \\
\hline \multicolumn{13}{|l|}{${ }^{*} p<0.05$} \\
\hline \multicolumn{13}{|l|}{${ }^{* * *} p<0.01$} \\
\hline${ }^{* * * *} p<0.001$ & & & & & & & & & & & & \\
\hline
\end{tabular}


make the decision of whether or not to save for retirement, or to make investment decisions about which assets to hold in the retirement portfolio. Our findings are also in line with previous studies showing that subjective financial knowledge has a significant impact on retirement planning and retirement investment management (Tang and Baker 2015). For retirement savings, the impact did however not reach the conventional level of statistical significance.

In order to measure F-BFL, we developed a new scale based on IRT (de Ayala 2009). In this respect, our results corroborate Knoll and Houts (2012) in that we likewise find that a short scale with questions covering a broad range of financial contents is possible to fit statistically to the accuracy of responses to survey questions. We also find that our short scale correlates $r=0.78$ with the scale frequently used in previous research to measure F-BFL, commonly referred to as the Big5 (Lusardi and Mitchell 2007). Given the central topics included in the Big5 and our scale, substantially different results should not be expected. Yet, given our method of developing the scale from a large number of questions covering additional topics and different levels of difficulty, we argue that our measure of F-BFL has a higher content validity. We were also able to replicate previous findings showing differences in financial literacy due to age, sex, and income.

We further showed that in all models of the relationship between fact-based and subjective financial literacy and retirement saving behaviours, our new uni-dimensional 16-question scale accounted for additional variance compared with the Big5. We thus provide a new F-BFL scale which is equally convenient to use as the Big5, and that may be chosen to augment the Big5 if improved accuracy is desired. We have accomplished this by increasing the number of content areas and by selecting questions with optimal difficulty to discriminate different levels of financial literacy.

The present results furthermore fill an important gap pointed out by Knoll and Houts (2012) in showing that responses to the survey items load on a single latent dimension of F-BFL. This finding has important bearings on the theoretical question of whether financial literacy is a unitary concept transcending several financial contents.

Our uni-dimensional F-BFL measure is positively related to how people perceive their knowledge of financial matters. Building on the conceptual division of the knowledge construct into objective and subjective financial knowledge, the observed significant positive correlation $(r=0.43)$ between the two is an additional contribution. Given the definition of financial literacy including how well an individual can understand and use personal finance-related information (Huston 2010), incorporating both subjective and FBFL is important.

\section{Implications for Policy and Future Research}

As stated, handling the increased responsibility regarding retirement income is of paramount importance for citizens all over the world. Hence, understanding the impact of financial literacy in the various phases of retirement financial behaviour has great relevance and has been the motivation for the present study. Sound financial behaviour may not necessarily be confined to the phases of retirement financial behaviour; a possible topic for future research would be to apply our developed financial literacy scale to study its relationship to a wider set of financial behaviour including switching of banks, use of credit cards, or even the search for financial information. A potential "single yardstick" for all financial behaviour is a desirable outcome, but it is not unlikely that we would need to develop different scales in trying to 
explain different types of financial behaviour. Another topic for future research would be to test our developed financial literacy scale in different countries that differ in their welfare/ retirement system structure to investigate whether the scale correlates with financial behaviour in these countries.

Focusing on the obtained results, we find support for a positive impact of F-BFL on all three types of retirement financial behaviour that were analysed. The Fernandes et al. (2014) meta-analysis measured F-BFL in a way similar to ours, and also detected a positive but weak impact on financial behaviour. Given that policymakers perceive the problem of insufficient retirement planning to be both imminent and of major importance, policies that increase knowledge associated with retirement issues are important. A follow-up question of this insight is if the effect of financial literacy may be increased by education. Fernandes et al. (2014) discuss the importance of having an opportunity to immediately enact and put to use the acquired knowledge since it would otherwise decay. In our case, the question is when the time is right to start educating people about saving for retirement. Is it at a certain age? Is it when entering a certain stage in life - as for example when getting the first job? The complexity of the question of retirement saving makes it even more challenging to specify the relation between education and financial behaviour given that our results show that there is a potential gain of education at different stages of financial retirement behaviour across the life span. An adequate measure of fact-based literacy is a starting point for raising and investigating such questions.

Another follow-up question is whether the demonstrated relation between a low level of FBFL and financial behaviour such as saving too little or refraining from investments in stocks could be used as a motivation for legislators to provide a presentation format that is easily processed even by individuals low in financial knowledge. By presenting not only information regarding mutual fund fees but also the outcome, in this case how much of the accumulated return over a savings period that is foregone by paying fund fees, it would be possible to overcome the negative relation between low financial fact-based literacy and stock investments. Examples of this legislation, i.e., presentation of fees as a dollar-amount, not as a percentage of capital, have been implemented in Sweden. Finally, it is worth mentioning that also the self-reported level of financial literacy had documented effects on primarily the stage where the individual plans his or her retirement savings. To initiate a pension saving process, it could hence be effective to stress in information campaigns that "it's not as complicated as it seems." If starting to act, both fact-based knowledge and confidence would be likely to increase.

Funding Information Open access funding provided by University of Gothenburg. Carlsson Hauff, Carlander, and Gärling have received financial support from Centre for Finance, School of Business, Economics and Law, University of Gothenburg, Sweden, through grant \#2010-02449 from the Swedish Agency for Innovation Systems (Vinnova) and Handelsbankens Stipendiestiftelser (P2015-0265:1).

Open Access This article is licensed under a Creative Commons Attribution 4.0 International License, which permits use, sharing, adaptation, distribution and reproduction in any medium or format, as long as you give appropriate credit to the original author(s) and the source, provide a link to the Creative Commons licence, and indicate if changes were made. The images or other third party material in this article are included in the article's Creative Commons licence, unless indicated otherwise in a credit line to the material. If material is not included in the article's Creative Commons licence and your intended use is not permitted by statutory regulation or exceeds the permitted use, you will need to obtain permission directly from the copyright holder. To view a copy of this licence, visit http://creativecommons.org/licenses/by/4.0/. 


\section{References}

Alba, J. W., \& Hutchinson, J. W. (1987). Dimensions of consumer expertise. Journal of Consumer Research, 13, 411-454.

Almenberg, J., \& Dreber, A. (2015). Gender, stock market participation and financial literacy. Economic Letters, $137,140-142$.

Almenberg, J., \& O. Widmark (2011). Numeracy and financial literacy among Swedish adults. Swedish Financial Supervisory Authority (Finansinspektionen), Report.

Behrman, J. R., Mitchell, O. S., Soo, C. K., \& Bravo, D. (2012). How financial literacy affects household wealth accumulation. American Economic Review, 102, 300-304.

Benartzi, S., \& Thaler, R. H. (2004). Save more tomorrow: Using behavioral economics to increase employee savings. American Economic Review, 91, 475-482.

Benartzi, S., \& Thaler, R. H. (2007). Heuristics and biases in retirement savings behavior. Journal of Economic Perspectives, 21(3), 81-104.

Bernheim, D., Garrett, D., \& Maki, D. (2001). Education and saving: The long-term effects of high school financial curriculum mandates. Journal of Public Economics, 85, 435-565.

Bloom, B., Engelhart, M. D., Furst, E. J., Hill, W. H., \& Krathwohl, D. R. (1956). Taxonomy of educational objectives: The classification of educational goals. Handbook I: Cognitive domain. New York, NY: David McKay Company.

Bucher-Koenen, T., A. Lusardi, R. Alessie, \& M. van Rooij (2014). How financially literate are women? An overview and new insights (Working Paper No. 20793). National Bureau of Economic Research.

Calvet, L., Campbell, J., \& Sodini, P. (2007). Down or out: Assessing the welfare costs of household investment mistakes. Journal of Political Economy., 115, 707-747.

Campbell, J. Y. (2006). Household finance. Journal of Finance, 61, 1553-1604.

Carlson, J. P., Vincent, L. H., Hardesty, D. M., \& Bearden, W. O. (2009). Objective and subjective knowledge relationship: A quantitative analysis of consumer research findings. Journal of Consumer Research, 35, $864-876$.

Carlsson Hauff, J., Carlander, A., Gamble, A., Gärling, T., \& Holmén, M. (2014). Storytelling as a means to increase consumers' processing of financial information. International Journal of Bank Marketing, 32, 495514.

Carlsson Hauff, J., Carlander, A., Gamble, A., Gärling, T., \& Holmén, M. (2016). Breaking the ice of low financial involvement: Does narrative information format from a trusted sender increase savings in mutual funds? International Journal of Bank Marketing, 34, 151-170.

Carmel, D., Carmel, E., Leiser, D., \& Spivak, A. (2015). Facing a biased adviser while choosing a retirement plan: The impact of financial literacy and fair disclosure. Journal of Consumer Affairs, 49, 576-595.

Chen, H., \& Volpe, R. (1998). An analysis of personal financial literacy among college students. Financial Services Review, 7, 107-128.

Chiou, J. S., Droge, C., \& Hanvanich, S. (2002). Does customer knowledge affect how loyalty is formed? Journal of Service Research, 5, 113-124.

de Ayala, R. J. (2009). The theory and practice of item response theory. New York, NY: Guilford Press.

Delavande, A., Rohwedder, S., \& Willis, R.J. (2008). Preparation for retirement, financial literacy and cognitive resources (Working Paper No. 2008-190). University of Michigan Retirement Research Center.

Devlin, J. F. (2011). Evaluative cues and services: The effect of consumer knowledge. Journal of Marketing Management, 27, 1366-1377.

Fernandes, D., Lynch Jr., J. G., \& Netemeyer, R. G. (2014). Financial literacy, financial education, and downstream financial behaviors. Management Science, 60, 1861-1883.

FSA. (2006). Financial capability baseline survey: Questionnaire. Consumer Research, 47b, March 2006. Financial Service Authority.

Graham, J. R., Harvey, C. R., \& Huang, H. (2009). Investor competence, trading frequency, and home bias. Management Science, 55, 1094-1106.

Grimes, P. W., Rogers, K. E., \& Smith, R. C. (2010). High school economic education and access to financial services. Journal of Consumer Affairs, 44, 317-335.

Gustman, A., Steinmeier, T., \& Tabatabai, N. (2012). Financial knowledge and financial literacy at the household level. American Economic Review, 102, 309-313.

Hadar, L., Sood, S., \& Fox, C. R. (2013). Subjective knowledge in consumer financial decisions. Journal of Marketing Research, 50, 303-316.

Hauff, J. (2006). Consumer decision-making regarding financial services: A study of consumer behavior within the Swedish premium pension system [Licentiate Dissertation]. Gothenburg: Gothenburg School of Business, Economics and Law. 
Hilgert, M. A., Hogarth, J. M., \& Beverly, S. (2003). Household financial management: The connection between knowledge and behavior. Federal Reserve Bulletin, 89(July), 309-322.

Hogarth, J., Anguelov, C. E., \& Lee, J. (2005). Who has a bank account? Exploring changes over time, 19892001. Joumal of Family and Economic Issues, 26, 7-30.

Hung, A., Parker, A. M. and Yoong, J. (2009). Defining and measuring financial literacy (RAND Working Paper, WR-708).

Huston, S. J. (2010). Measuring financial literacy. Journal of Consumer Affairs, 44, 296-316.

Katsikopoulos, K. V. (2011). Psychological heuristics for making inferences: Definition, performance, and the emerging theory and practice. Decision Analysis, 8, 10-29.

Knoll, M. Z., \& Houts, C. R. (2012). The financial knowledge scale: An application of item response theory to the assessment of financial literacy. Journal of Consumer Affairs, 46, 381-410.

Lusardi, A. (2009). The importance of financial literacy. NBER Reporter, 2.

Lusardi, A., \& Mitchell, O. S. (2007). Baby boomer retirement security: The roles of planning, financial literacy, and housing wealth. Journal of Monetary Economics, 54(January), 205-224.

Lusardi, A. \& Mitchell, O. S. (2008). Planning and financial literacy: How do women fare? American Economic Review, 98, 413-417.

Lusardi, A., Mitchell, O.S., \& Curto, V. (2010). Financial literacy among the young: Evidence and implications for consumer policy (Working Paper 2008:191), University of Michigan Retirement Research Center.

Lyons, A.C. (2007). Credit practices and financial education needs of Midwest college students (Networks Financial Institute at Indiana State University Working Paper, Working Paper 2007-23).

Lusardi, A. \& Mitchell, O. S. (2014). The economic importance of financial literacy: Theory and evidence. Journal of Economic Literature, 52, 5-44.

Madrian, B. C., \& Shea, D. F. (2001). The power of suggestion. Inertia in 401(k) participation and savings behaviour. Quarterly Journal of Economics, 116, 1149-1187.

Mandell, L. (2003). Financial literacy: Improving education. National Jump\$start Coalition Survey.

Mansfield, P., \& Pinto, M. (2008). Consumer vulnerability and credit card knowledge among developmentally disabled citizens. Journal of Consumer Affairs, 42, 425-438.

McKenzie, C. R., \& Liersch, M. J. (2011). Misunderstanding savings growth: Implications for retirement savings behavior. Journal of Marketing Research, 48, S1-S13.

Modigliani, F. (1986). Life cycle, individual thrift, and the wealth of nations. American Economic Review, 76, 297-313.

Monticone, C. (2010). How much does wealth matter in the acquisition of financial literacy? Journal of Consumer Affairs, 44, 403-422.

Moorman, C., Diehl, K., Brinberg, D., \& Kidwell, B. (2004). Subjective knowledge, search locations, and consumer choice. Journal of Consumer Research, 31, 673-680.

Munnell, A. H., Webb, A., \& Golub-Sass, F. (2007). Is there really a retirement savings crisis? An NRRI analysis. Center for Retirement Research at Boston College, 7-11.

Muthén, L. K., \& Muthén, B. O. (1998-2012). Mplus user's guide (7th ed.). Los Angeles, CA: Muthén \& Muthén.

Nicolini, G., Cude, B. J., \& Chatterjee, S. (2013). Financial literacy: A comparative study across four countries. International Journal of Consumer Studies, 37, 689-705.

Nicolini, G., Gärling, T., Carlander, A., \& Carlsson Hauff, J. (2017). Attitude towards risk and financial literacy in investment planning. In A. Carretta, F. Fiordelisi, \& P. Schwizer (Eds.), Risk culture in banking (pp. 309320). New York, NY: Springer.

Noctor, M., Stoney, S., \& Stradling, S. (1992). Financial literacy: A discussion of the concepts and competencies of financial literacy and opportunities for its introduction into young people's learning. National Foundation for Educational Research.

O’Neil, B. (2003). A preliminary assessment of financial practices: The financial fitness quiz. Journal of Personal Finance, 2, 22-28.

Ooijen, R., Alessie, R., \& Kalwij, A. (2015). Saving behavior and portfolio choice after retirement. EconomistNetherlands, 163(3), 353-404.

Perry, V. G., \& Morris, M. D. (2005). Who is in control? The role of self-perception, knowledge, and income in explaining consumer financial behavior. Journal of Consumer Affairs, 39, 299-313.

Poterba, J. M., Venti, S. F., \& Wise, D. A. (2008). New estimates of the future path of 401(k) assets. NBER/Tax Policy \& the Economy (University of Chicago Press), 22, 43-80.

Remund, D. L. (2010). Financial literacy explicated: The case for a clearer definition in an increasingly complex economy. Journal of Consumer Affairs, 44, 276-295.

Schaefer, A. (1997). Consumer knowledge and country of origin effects. European Journal of Marketing, 31, 56-72. 
Schooley, D. K., \& Drecnik Worden, D. (2013). Accumulating and spending retirement assets: A behavioral finance explanation. Financial Services Review, 22, 173-186.

Simon, H. A. (1955). A behavioral model of rational choice. The Quarterly Journal of Economics, 69, 99-118.

Tang, N., \& Baker, A. (2015). Self-esteem. Financial knowledge and financial behavior. Journal of Economic Psychology, 54, 164-176.

Thaler, R. H., \& Sunstein, C. R. (2008). Nudge: Improving decisions about health, wealth, and happiness. New Haven, CT: Yale University Press.

van Rooij, M., Lusardi, A., \& Alessie, R. J. (2011). Financial literacy and stock market participation. Journal of Financial Economics, 101, 449-472.

van Rooij, M. C., Lusardi, A., \& Alessie, R. J. (2012). Financial literacy, retirement planning and household wealth. Economic Journal, 122, 449-478.

Vissing-Jorgensen, A. (2004). Perspectives on behavioral finance: Does 'irrationality' disappear with wealth? Evidence from expectations and actions. NBER Macroeconomics Annual, 18, 139-208.

Vitt, L. A., Anderson, C., Kent, J., Lyter, D. M., Siegenthaler, J. K., \& Ward, J. (2000). Personal finance and the rush to competence: Financial literacy education in the U.S. Middleburg: Institute for Socio-Financial Studies.

Weber, E. U. (2004). Who's afraid of a poor old age? Risk perception and risk management decisions. In O. S. Mitchell \& S. P. Utkus (Eds.), Pension design and structure. Oxford: Oxford University Press.

Worthington, A. (2006). Predicting financial literacy in Australia. Financial Services Review, 15, 59-79.

Publisher's Note Springer Nature remains neutral with regard to jurisdictional claims in published maps and institutional affiliations. 